\title{
ESTIMATION OF PEAK GROUND ACCELERATION OF RANAU BASED ON RECENT EARTQHUAKE DATABASES
}

Noor Sheena Herayani Binti Harith1, Azlan Adnan2

1 Civil Engineering Program, Engineering Faculty, Universiti Malaysia Sabah, 88400 Kota Kinabalu, Sabah, Malaysia. ${ }^{2}$ Faculty of Civil Engineering, Universiti Teknologi Malaysia, 81310, Johor Bahru, Malaysia.

This is an open access article distributed under the Creative Commons Attribution License, which permits unrestricted use, distribution, and reproduction in any medium, provided the original work is properly cited.

\section{ARTICLE DETAILS}

\section{ARTICLE HISTORY:}

Received 12 May2017

Accepted 12 July 2017

Available online 10 September 2017

\section{KEYWORDS}

Ranau, low to moderate earthquake, peak ground acceleration, probability of exceedance

\section{ABSTRACT}

The occurrence of earthquake with magnitude $\mathrm{M}_{\mathrm{W}} 6.0$ in Ranau recently has triggered many questions regarding their nature of recurrence, characteristics in size and mechanism in and its surrounding region. In recent years, Sabah has witnessed an increase in low to moderate seismic activities due to the causative ground structures which reflected in their seismic productivities. Over the past years between 1900 until recently, magnitudes ranging from $\mathrm{M}_{\mathrm{W}} 2.9$ to 6.0 were known to have occurred. While large magnitude earthquakes are fortunately rare, in the history of earthquakes, the region already experienced devastating earthquake including a magnitude of Mw 5.8 on 26 th July 1976 centred in Lahad Datu. The observation on earthquake catalogue spanning from 1900 to 2014 has been obtained from various earthquake data centers, Ranau previously recorded an earthquake with magnitude Mw 5.1 , the repeat over intervals of sudden large earthquake is considered to have much shorter recurrence intervals. This paper discusses the procedure for evaluating the probabilistic seismic hazard analysis (PSHA) whereas the peak ground acceleration (PGA) on bedrock of Ranau area for $10 \%$ and $2 \%$ probability of exceedance is taken into account. By analysing the correlation between the tectonic features and the available data on past seismicity, the estimation of PGA is based on smoothed-gridded seismicity with a subjectively chosen correlation distance of 50 $\mathrm{km}$. The PGA estimation values for Ranau are approximately in the range of 80 to $140 \mathrm{~cm} / \mathrm{s}^{2}$ that will be exceeded $10 \%$ probability of exceedance and 140 to $250 \mathrm{~cm} / \mathrm{s}^{2}$ for $2 \%$ probability of exceedance.

\section{INTRODUCTION}

Sabah is considered as a stable continental shield region at the triple junction zone of convergence between the Philippine, Indian-Australian and Eurasian Plates. The seismicity is classified as a low to moderate earthquake with damaging earthquakes are fortunately rare however, in recent years, Sabah has witnessed an increase in low to moderate seismic activities due to a few active local fault lines including the Belait, Crocker, Jerudong Fault, Mensaban, Mulu faults and the Pegasus Tectonic Line as illustrated in Figure 1.1 [1]. The recent earthquake occurred in Ranau with moment magnitude $\left(\mathrm{M}_{\mathrm{w}}\right)$ of 6.0 at a depth of approximately $10 \mathrm{~km}$ and lasted 30 seconds caused serious damage to many infrastructure and can felt as far as $400 \mathrm{~km}$ from the epicentre. This was the strongest and worst earthquake ever affected Malaysia since 1976 with approximately 8 people died due to this event.

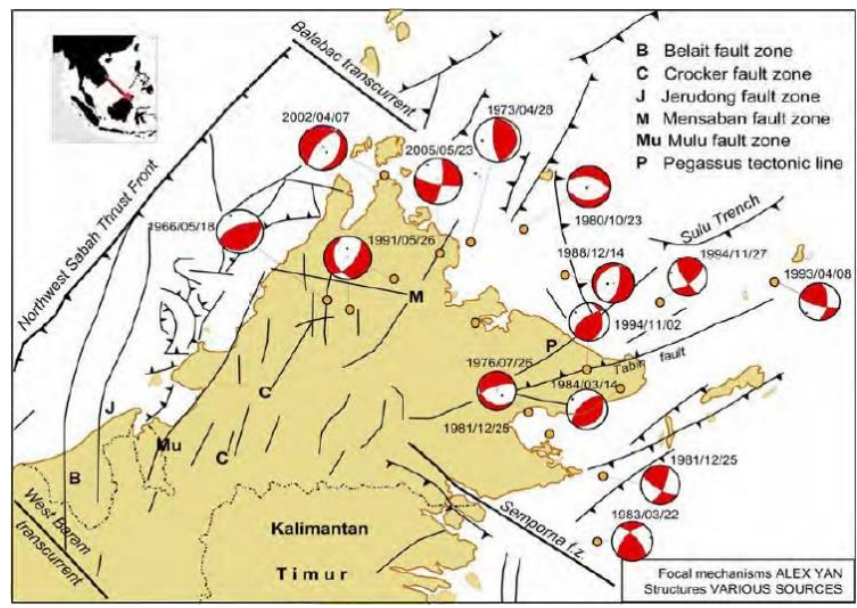

Figure 1.1:Seismic geometry of local earthquake around Sabah [1]
The national catalogue compiled from historical and instrumental recordings from 1874 to 2014 for a magnitude of 2.0 or above in the vicinity of East Malaysia is taken into consideration, with total data accumulated of 159 earthquakes (Figure 1.2). The oldest report made in 1985 which mentioned the lack of accuracy of earthquakes recorded before 1900, since there were only two earthquake events [2]. At present, it is not possible to check the validity of these data; however, a continuing monitoring will help to bring insight to this issue in the future. Therefore, it is omitted in the current study. The catalogue made by the same researcher also contains detailed information about the damage experienced based on public observations in terms of intensity [2].

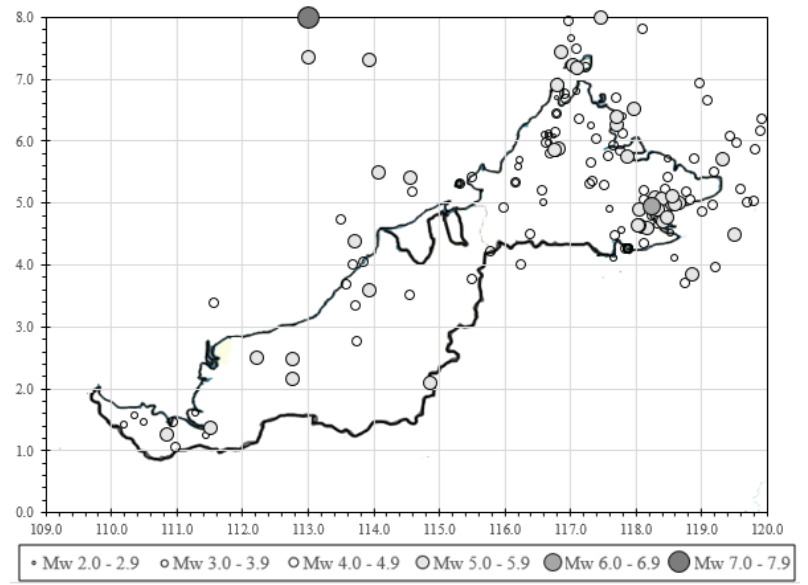

Figure 1.2: $\quad$ Distribution of local background epicentres with a magnitude ranging from 2.0-7.9 around East Malaysia from 1874 until 2014

There is some researcher also has mentioned the local background 
source having occurred across East Malaysia and the lack of information regarding the events [3]. Previous studies have mentioned some local earthquakes having occurred from local active faults $[1,2,4]$. In a study, the seismicity that was scattered heterogeneously was grouped by the same seismic characteristics in a space [5]. The earthquake scattered around Sabah is divided into three seismic zones: Central-North, Labuk Bay-Sandakan Basin, and Dent-Semporna Peninsular (Figure 1.3).

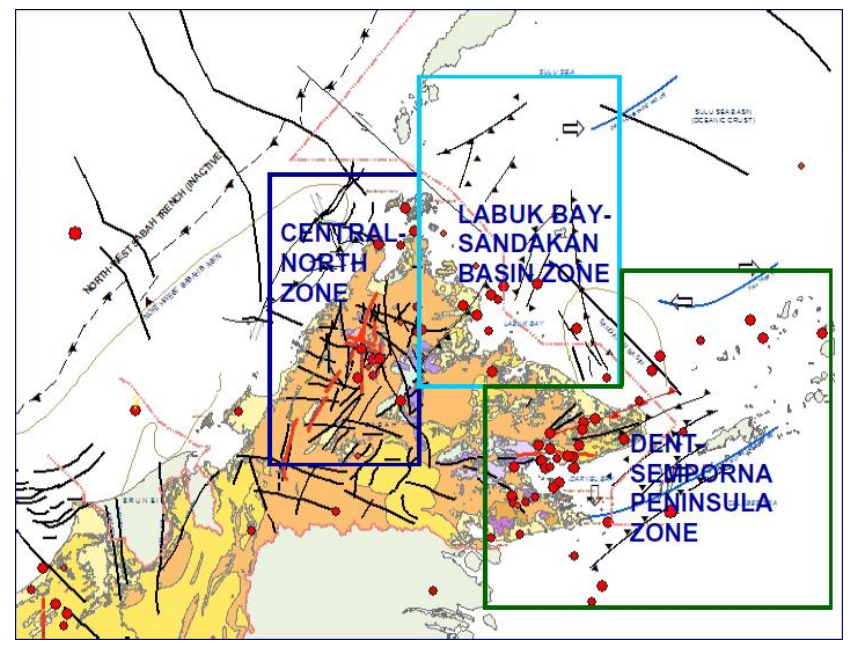

Figure 1.3:

Seismic zone of Sabah, as illustrated in the MMD report [5]

The earliest seismic hazard study for East Malaysia seismicity was based on intensities by a researcher [2]. Intensity is a simple classification of indirect and non-objective strength of ground motion based on observed effects. Only in 2007 was a conversion of this seismic map to peak ground acceleration performed by MMD. In 1999, the seismic hazard map for the East Malaysia region can be found from the Global Seismic Hazard Assessment Program (GSHAP) [6]. In accordance with the map, Ranau region shows that the peak ground acceleration (PGA) estimation for the region which is available for $10 \%$ probability of exceedance is between 80 and $160 \mathrm{~cm} / \mathrm{s}^{2}$. There have been few recent hazard maps published for the region. As an example, the seismic hazard map used probabilistic analysis and the website of the USGS [7,8,3]. A researcher has produced a seismic hazard map by considering the earthquake hazard associated with Sumatran subduction and faults $[7,8]$.

The PGA maps show that the PGA trends are between 1.0 and $294 \mathrm{~cm} / \mathrm{s}^{2}$ for $2 \% \mathrm{PE}$ and between 19.6 and $98.1 \mathrm{~cm} / \mathrm{s}^{2}$ for $10 \%$ PE $[7,8]$. One of study presents the hazard map for $2 \%$ PE being between 160 and $180 \mathrm{~cm} / \mathrm{s}^{2}$ and for $10 \%$ PE trends being between 60 and $80 \mathrm{~cm} / \mathrm{s}^{2}$ by applying the seism tectonic area within Sulawesi and Kalimantan [3]. In the USGS hazard map, the $10 \%$ PE shows the PGA values being between 29.4 and $147.2 \mathrm{~cm} / \mathrm{s}^{2}$. Concerning the latest PGA analyzed by applying the Preliminary Hybrid Seismic Response Spectrum Model, the 2\% PE is given between 100 and $180 \mathrm{~cm} / \mathrm{s}^{2}$ (with no further result on $10 \% \mathrm{PE}$ ) [9].

The inconsistency in terms of PGAs might be due to seism tectonic zoning or GMPE selection in estimating the hazard level. In order to remedy this situation, a new analysis of PSHA using a consistent set of low-to-moderate earthquake recordings is presented in this study. Table 1.1 shows the summary of PGAs estimated from different publications with $10 \%$ and $2 \%$ probability of exceedance for an exposure time of 50 years, which corresponds to a return period of 475 and 2,475 years, respectively, with site classification being bedrock. PGA predicted values for $10 \%$ and $2 \%$ probability of

Table 1.1:

exceedance in Ranau

\begin{tabular}{|c|c|c|}
\hline Reference & $\begin{array}{l}10 \% \\
\left(\mathrm{~cm} / \mathrm{s}^{2}\right)\end{array}$ & $\begin{array}{l}2 \% \\
\left(\mathrm{~cm} / \mathrm{s}^{2}\right)\end{array}$ \\
\hline Giardini et al. (1999) & $\begin{array}{ll}80.0 & - \\
160.0\end{array}$ & $N / A$ \\
\hline Petersen et al. $(2007,2008)$ & $\begin{array}{l}19.6- \\
98.1 \\
\end{array}$ & $\begin{array}{l}1.0- \\
294.0\end{array}$ \\
\hline $\begin{array}{l}\text { United States Geological } \\
\text { Survey (2008) }\end{array}$ & $\begin{array}{l}29.4- \\
147.2 \\
\end{array}$ & $N / A$ \\
\hline Adnan et al. (2008) & $\begin{array}{l}60.0- \\
80.0 \\
\end{array}$ & $\begin{array}{l}160.0- \\
180.0\end{array}$ \\
\hline Hee (2014) & $N / A$ & $100.0-$ \\
\hline
\end{tabular}

\begin{tabular}{|l|l|l|}
\hline & & 180.0 \\
\hline Note: $N / A=$ Data not available &
\end{tabular}

Low-to-moderate numbers from MW 2.8-7.4 shallow-depth earthquake events of the Modified Mercalli Intensities Scale range from III to VIII $[10,11]$. A statement made by a researcher mentioned that the conditions with low magnitude may have a significant impact on the hazard level [12]. The range of intensity approximately correlates with PGA in the range of 150 to $160 \mathrm{~cm} / \mathrm{s}^{2}$. However, the MMI scale was increased to VIII, where the PGA was predicted as being between 340 and $650 \mathrm{~cm} / \mathrm{s}^{2}$, as illustrated in Figure 1.4 .

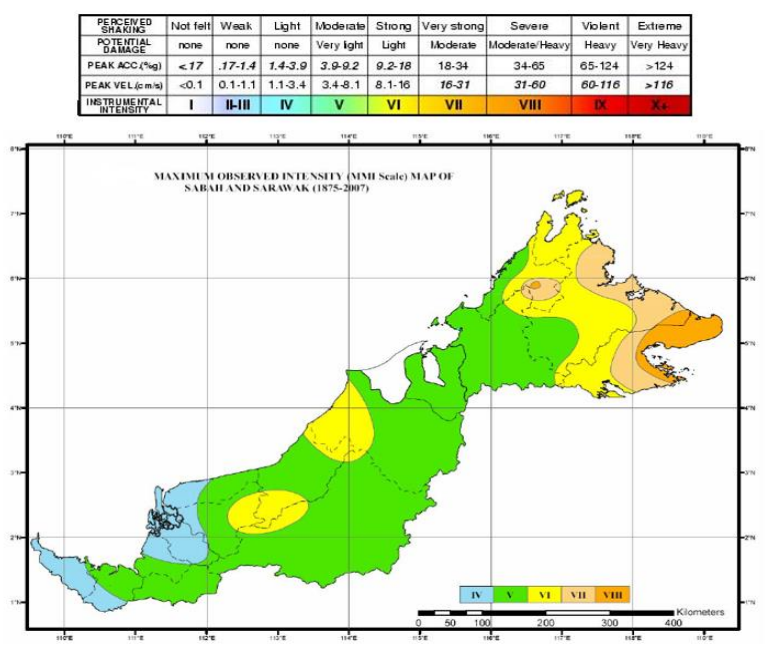

Figure 1.4: Modified Mercalli Intensity (MMI) of East Malaysia [5]

\section{SEISMIC HAZARD ANALYSIS}

The earthquake sources generally are not well defined in regions of low-to-moderate seismicity, and generally the maximum magnitude estimates have relatively long return periods. Based on this, probabilistic seismic hazard analysis (PSHA) is considered to be the best means of representing the uncertainties and defining the peak ground acceleration for the region. The PSHA is a mathematical procedure involving a probabilistic study to assess the answer for uncertainties about seismic location, earthquake size and shaking intensity that might happen in the future. Two of common methodology used describing the PSHA procedure can be seen in two studies $[13,14]$. The method also being updated in study which describe the procedure of PSHA clearly [15].

The earthquake data catalogue is processed by three common analyses, such as earthquake size analysing, decluttering earthquake events, which is eliminating foreshock and aftershock from the main earthquake event, and lastly incompleteness analysis. Then, the potential seismic source is identified, including low rate seismic activity and regional seismic source zones that are believed to be tectonically active. A common practice in seismic hazard analysis is to define earthquake sources, so therefore it is necessary to make some scientific earthquake studies in estimation of seismicity parameters of defined source zones. By estimating the amplitudes of a parameter describing the ground motion or the earthquake effect based on smoothed-gridded seismicity with a subjectively chosen correlation distance of $50 \mathrm{~km}$ covering the complete area of a big city or an entire state, zoning maps can be developed by contouring the sub-areas with equal hazard as shown in Figure 1.6.

The basic input for the seismic hazard analysis is the source model, expressed through the Gutenberg-Richter activity parameters a- and bvalue for each of the seismic zones. The a-value gives the rate of occurrence of events larger than a certain magnitude (intercept of the curve of the sum of all zones) and b-value gives the relative distribution of small and large events or the slope of the line. The current study used the 31 seismic zones including isolated and local seismic sources. The seismicity can be characterized with the Gutenberg and Richter relation using the formula: $\log _{10} \lambda=a-b M$ where $\lambda$ is the rate of earthquake with $\mathrm{a}$ and $\mathrm{b}$ are constant [16].

Due to the small dataset available in background sources, the determination of $b$ for separate zones are determined as well as the maximum magnitude for each zone by means of the earthquake catalogue. In each zone a maximum magnitude that has ever been recorded can be found. For the choice of minimum magnitude, one would 
expect that it does not strongly influence the hazard estimate, because small magnitudes do not cause damage. The identification of the maximum and minimum magnitude $\left(\mathrm{M}_{\max }\right.$ and $\left.\mathrm{M}_{\min }\right)$ in each seismic source is expected to be varies and it is defined by referring to the earthquake catalogue. The a- and b-value were converted to $\alpha$ and $\beta$ where $\alpha=2.303 \mathrm{a}$ and $\beta=2.303 \mathrm{~b}$ which imply that the earthquake magnitudes are exponentially distributed. The input parameters that were considered for the final seismic hazard, such as $\alpha, \beta$, recurrence rate, $\lambda$ and maximum size of future earthquakes for each source, are given in Table 1.2. Since hazard calculations are quite sensitive to the $b$-value, the use of these values will be separately for each zone.

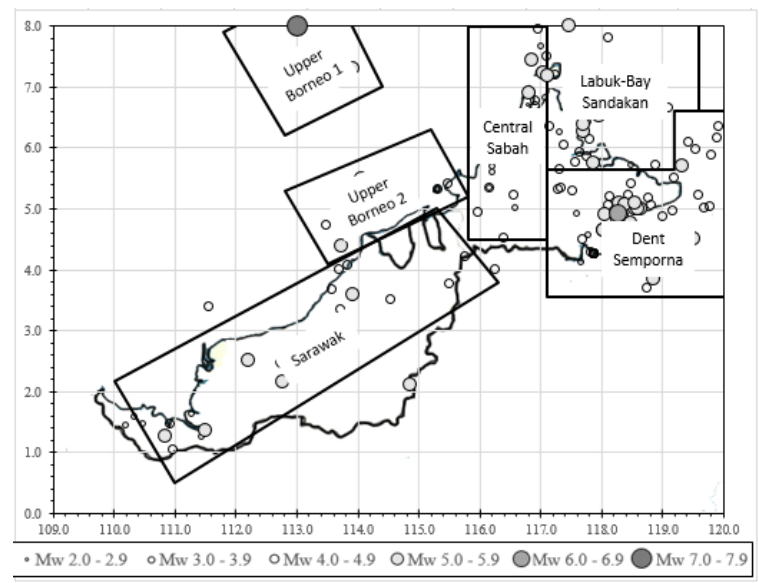

Figure 1.5:

Background source proposed in this study Table 1.2:

Recurrence parameters East Malaysia source zones

\begin{tabular}{|c|c|c|c|c|c|c|c|}
\hline urce & $\begin{array}{l}\text { Typ } \\
\text { e }\end{array}$ & Name & $\alpha$ & $\boldsymbol{\beta}$ & $\lambda$ & $\begin{array}{l}\text { Mmi } \\
\text { n }\end{array}$ & $\begin{array}{l}\text { Mma } \\
\mathrm{x}\end{array}$ \\
\hline \multirow[t]{6}{*}{$\begin{array}{l}\text { Backgrou } \\
\text { nd }\end{array}$} & \multirow[t]{6}{*}{ Area } & Sarawak & $\begin{array}{l}4.67 \\
2\end{array}$ & $\begin{array}{l}1.44 \\
1\end{array}$ & $\begin{array}{l}0.42 \\
4\end{array}$ & 3.5 & 5.3 \\
\hline & & $\begin{array}{l}\text { Upper } \\
\text { Borneo } 1\end{array}$ & $\begin{array}{l}3.14 \\
1\end{array}$ & $\begin{array}{l}1.07 \\
6\end{array}$ & $\begin{array}{l}0.23 \\
8\end{array}$ & 5.0 & 7.0 \\
\hline & & $\begin{array}{l}\text { Upper } \\
\text { Borneo } 2\end{array}$ & $\begin{array}{l}4.67 \\
2\end{array}$ & $\begin{array}{l}1.44 \\
1\end{array}$ & 0.42 & 3.5 & 5.8 \\
\hline & & $\begin{array}{l}\text { Central } \\
\text { Sabah }\end{array}$ & $\begin{array}{l}5.29 \\
1\end{array}$ & $\begin{array}{l}1.79 \\
0\end{array}$ & $\begin{array}{l}1.25 \\
8\end{array}$ & 2.9 & 6.0 \\
\hline & & $\begin{array}{l}\text { Labuk } \\
\text { Bay } \\
\text { Sandaka } \\
\text { n }\end{array}$ & $\begin{array}{l}4.52 \\
7\end{array}$ & $\begin{array}{l}1.40 \\
3\end{array}$ & $\begin{array}{l}0.41 \\
2\end{array}$ & 3.5 & 6.7 \\
\hline & & $\begin{array}{l}\text { Dent } \\
\text { Semporn } \\
\text { a }\end{array}$ & $\begin{array}{l}7.47 \\
2\end{array}$ & $\begin{array}{l}2.18 \\
4\end{array}$ & $\begin{array}{l}8.32 \\
7\end{array}$ & 3.0 & 6.3 \\
\hline
\end{tabular}

Since this study does not aim at considering the full epistemic uncertainties usually contained in a PSHA, this study is restricted to applying few GMPEs to fulfil the criteria of Ranau being affected mostly by shallow crustal faults and evaluated to highlight their limitation in terms of magnitude and distance. These include equations [17-21].

\section{RESULTS}

The mean annual rate of incidence for PSHA was calculated from the combination of all input parameters (i.e. earthquake catalogue, seismic hazard parameters and GMPE). The hazard maps are depicted in terms of peak ground acceleration (PGA) at bedrock level of $10 \%$ and $2 \%$ probability of exceedance in 50-year return period corresponds to 475 and 2,475 years, respectively. Figure 1.7 shows the results of this test. The PGA values are approximately in the range of 80 to $140 \mathrm{~cm} / \mathrm{s}^{2}$ that will be exceeded in a period of 475-years. Obviously, the image is very similar to the Modified Mercalli Intensity (MMI) scale of East Malaysia prepared by Leyu [5]. However, the PGAs are still low in Sarawak area. The PGA values investigated are still in the expected range, except for other studies which fall outside the targeted range [6].

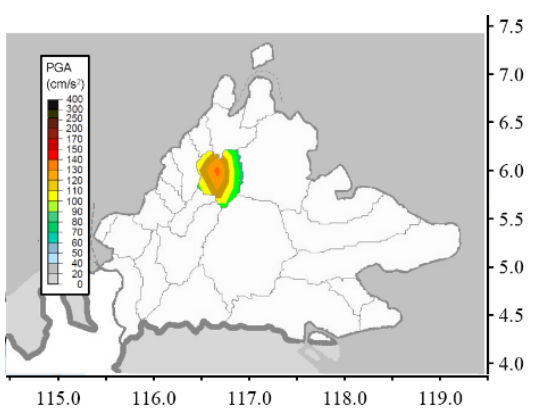

Figure 1.6:

PGA hhazard map with $10 \%$ probability of exceedance for 50 years (475-year return period) for zonation of background point sources

The resulting seismic hazard map for a $2 \%$ probability of exceedance from background source zonation is as shown in Figure 1.8. The highest PGA values obtained is approximately 140 to $250 \mathrm{~cm} / \mathrm{s}^{2}$. The results are difficult to compare to the hazard map of this study, since the seismic hazard assessment was based on intensities, rather than the PGA [5]. However, the conversion of intensities to PGA seems to agree fairly well with the accelerations found in this study.

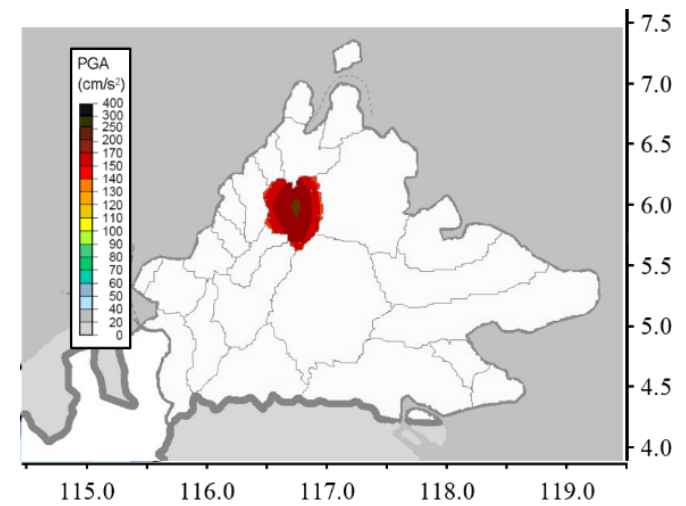

Figure 1.7: $\quad$ PGA hhazard map with 2\% probability of exceedance for 50 years (2,475-year return period) for zonation of background point sources.

\section{CONCLUSION}

The outcome described in this research forms the definition of PSHA results using the most updated earthquake data records between year 1900 to 2014. The contour maps were produced for mean PGA at 5\% critical damping ratio of $10 \%$ and $2 \%$ probability of exceedance (corresponding to 475 and 2,475 year return periods, respectively) in design time period of 50 years. The probabilistic hazard maps represented by PGA for Ranau is in the range of 80 to 140 $\mathrm{cm} / \mathrm{s}^{2}$, corresponding to the 475-year return period and in the range of 140 to $250 \mathrm{~cm} / \mathrm{s}^{2}$, corresponding to the 2,475-year return period. Although the earthquakes in Sabah is characterized by a fairly low magnitude with fortunately a rare occurrence of a large earthquake, the seismic hazard must be considered for important structures such as nuclear power plants, dams, oil platforms, etc.

\section{REFERENCES}

[1] Alexander, Y., Suratman, S., Liau, A., Hamzah, M., Ramli, M. Y., Ariffin, H., Abd. Manap, M., Mat Taib, M. B., Ali, A. and Tjia, H. D. 2006. Study on the Seismic and Tsunami Hazards and Risks in Malaysia. In: (JMG), M. A G. D. M. (ed.) Report on the Geological and Seism Tectonic Information of Malaysia. Kuala Lumpur: Ministry of Natural Resources and Environment.

[2] Leyu, C. H., Chong, C. F., Arnold, E.P., Kho, Sai-L., Lim, Y. T. Subramaniam, M., Ong, T. C.,Tan, C. K., Yap, K. S., Shu, Y. K. and Goh, H. L. 1985. Series on Seismology Malaysia. In: Arnold., E. P. Southeast Asia Association of Seismology and Earthquake Engineering (SEASEE).

[3] Adnan, A., Hendriyawan, A. M., and Selvanayagam, P.N. and Marto. A (ed.) 2008. Development of Seismic Hazard Maps of East Malaysia: Advances in Earthquake Engineering Application, UTM.

[4] Mohd Hazreek, Z. A., R. S., Fauziah Ahmad, Devapriya Chitral Wijeyesekera and Mohamad Faizal Tajul Baharuddin 2012. Seismic 
Refraction Investigation on Near Surface Landslides at the Kundasang area in Sabah, Malaysia. Procedia Engineering, 50, 516-531.

[5] Leyu, C. H. 2009. Seismic and Tsunami Hazards and Risks Study in Malaysia. In: MOSTI (ed.) Summary for Policy Makers.

[6] Giardini, D., Grünthal, G., Shedlock, K. M. and Zhang, P. 1999. The GSHAP Global Seismic Hazard Map.

[7] Petersen, M. D., Harmsen, S., Mueller, C., Haller, K., Dewey, J., Luco, N., Crone, A., Lidke, D. and Rukstales, K. 2007. Documentation for the Southeast Asia seismic hazard maps. Administrative Report September 30, 2007.

[8] Petersen, M. D., Harmsen, S., Mueller, C., Haller, K., Dewey, J., Luco, N., Crone, S., Rukstales, K. and Lidke, D. 2008. New Usgs Southeast Asia Seismic Hazard Maps. In: WCEE, ed. World Conference on Earthquake Engineering, October 12-17, Beijing, China. WCEE.

[9] Hee, M. C. 2014. Preview of Natinal Annex to EC8: Seismic Loadings for Peninsular Malaysia, Sabah and Sarawak. Jurutera: The Monthly Bulletin of the Institution of Engineers, Malaysia. Institution of Engineers, Malaysia.

[10] Majid, T. A., Zaini, S. S., Nazri, F. M., Arshad, M. R. and Suhaimi, I. F. M. 2007. Development of Design Response Spectra for Northern Peninsular Malayisa Based on UBC 97 Code. The Institution of Engineers Malaysia, 68, 7.

[11] United State Geological Survey, U. and N. E. I. C., NEIC. 2008. Seismic Hazard of Western Indonesia [Online]. USGS and NEIC. Available: http://earthquake.usgs.gov/research/hazmaps/products_data/ [Accessed 15 February 2013]

[12] Delavaud, E., Cotton, F., Akkar, S., Scherbaum, F., Danciu, L., Beauval, C., Drouet, S., Douglas, J., Basili, R. and Sandikkaya, M. A. 2012. Toward a ground-motion logic tree for probabilistic seismic hazard assessment in Europe. Journal of Seismology, 16 (3), 451-473.
[13] Cornell, C. A. 1968. Engineering seismic risk analysis. Bulletin of the Seismological Society of America, 58 (5), 1583-1606.

[14] Reiter, L. 1991. Earthquake Hazard Analysis: Issues and Insights. New York, NY: Columbia University Press.

[15] Baker, J. W. 2013. Probabilistic Seismic Hazard Analysis, White Paper Version.

[16] Gutenberg, B., and Richter, C. F. 1956. Earthquake Magnitude, Intensity, Energy, and Acceleration (Second Paper). Seismological Society of America Bulletin, 46 (2), 105-145.

[17] Sadigh, K., Chang, C.-Y., Egan, J.A., Makdisi, F. and Youngs, R.R. 1997. Attenuation Relationships for Shallow Crustal Earthquakes Based on California Strong Motion Data. Seismological Research Letters, 68 (1), 180-189.

[18] Fukushima, Y., Köse, O., Yürür, T., Volant, P., Cushing, E., and Guillande, R. 2002. Attenuation Characteristics of Peak Ground Acceleration from Fault Trace of the 1999 Kocaeli (Turkey) Earthquake and Comparison of Spectral Acceleration with Seismic Design Code. Journal of Seismology, 6 (3), 379-396.

[19] Pan, T.-C., and Megawati, K. 2002. Estimation of peak ground accelerations of the Malay Peninsula due to distant Sumatra earthquakes. Bulletin of the Seismological Society of America, 92 (3), 1082-1094.

[20] Campbell, K. W. 2003a. Erratum to Prediction of Strong Ground Motion Using the Hybrid Empirical Method and Its Use in the Development of Ground-Motion (Attenuation) Relations in Eastern North America. Bulletin of the Seismological Society of America, 93, 1012-1033.

Campbell, K. W. 2003b. Prediction of Strong Ground Motion Using the Hybrid Empirical Method and Its Use in the Development of GroundMotion (Attenuation) Relations in Eastern North America. Bulletin of the Seismological Society of America, 93, 1012-1033. 